\title{
Social Responsiveness of Higher Education: Access, Equity and Social Justice
}

\author{
Solomon Arulraj David \\ Faculty of Education, The British University in Dubai (BUiD), Dubai, United Arab Emirates. \\ Email: solomon.david@buid.ac.ae
}

Received August 31, 2016; Revised September 22, 2016; Accepted November 05, 2016; Published January 14, 2017

\begin{abstract}
The purpose of this study is to understand and present multiple perspectives on the trends and developments on access to higher education in India. It particularly aims to contribute to the ongoing debate on access, equity and social justice as part of social justice demand for higher education. Higher education institutions in India use three approaches to admit students, namely; classical - merit/elite door, social responsive - reservation door and economic responsive - financial interest door or the combination of the three, depending on their status and background such as public, private aided, private unaided. The study consulted relevant documents and literature to understand the problem, gathered empirical data through semi-closed qualitative interviews and used critical reflection and social constructivism approach to analyse and discuss the results. The findings indicate that some of the respondents support merit/elite door, some favour reservation door, some demand fair and square reservation system, some others seem to accept financial interest door, while some others support the combination of the two or the three approaches. The findings confirmed the initial assumption of the study that privatisation of higher education and the emergence of self-financing programmes and institutions have slowed down and posed new challenges to the social justice agenda. The study argues that it is important that higher educational institutions to uphold social responsiveness by embracing equity and social justice. Moreover, it is important to raise conscious about the social responsiveness of higher education among various stakeholders and accounting divergent perspectives contribute to engineer fair and just society.
\end{abstract}

Keywords: Access, Equity, Social Justice, Social Responsiveness, Higher Education, India

\section{Introduction}

Access to higher education in India during the last three decades has expanded and particularly driven by privatisation. According to all India survey on higher education (2015), $76 \%$ of the colleges are privately managed with $15 \%$ aided $61 \%$ unaided. Although private and community participation has been part of Indian education system for long time, more in a philanthropic sense, the emergence of for-profit education has been a recent phenomenon (Agarwal, 2007). The privatisation trend particularly slowed the popular democratic development for inclusion of the traditionally excluded groups in higher education through reservation. Fraser (2008) points out two forms of injustice to the marginalized community; the first is cultural and symbolic, the second is socio-economic injustice. The socio-economic injustice poses the neo marginalization caused by privatization trends where financial merit is valued than academic merit which does not support equity and social justice demands (David, 2014) as the privatisation and

(c) AesthetixMS 2016. This Open Access article is published under a Creative Commons Attribution Non-Commercial 4.0 International License (http://creativecommons.org/licenses/by-nc/4.o/), which permits non-commercial re-use, distribution, and reproduction in any medium, provided the original work is properly cited. For citation use the DOI. For commercial re-use, please contact editor@rupkatha.com. 
commercialization dynamics have reduced the opportunity for the marginalized and have created double standards for haves and have-nots.

Gross enrollment ratio (GER) of female students, scheduled caste, scheduled tribe students and Muslim students are lower than the national GER average (The twelfth plan, 2012). Similar trend is identified also in the four higher education institutions studied in this research that present different scenario based on their status such as centrally funded, state funded, private aided and private unaided. Higher education institutions use different approaches to admit students, such as the classical - merit door, social responsive - reservation door and economic responsive - financial interest door based on their value and status.

The objectives of the study is to understand the general trends on access to higher education in India, particularly in relation to access, equity and social justice, through literature review, document analysis and to present multiple perspectives emerged through interviewing relevant stakeholders. The study is keen to explore the following research questions: 1 . What are the trends of access to higher education in India? 2. How does the social justice agenda for access to higher education in India is approached? 3. What are the views of different stakeholders (in India) in higher education for access, equity and social justice? 4. And how are these views contribute to shape the trends on access to higher education in relation to the social responsiveness demand?

The interview analysis provide different views and perspectives about the trends on access and the way the problem has to be dealt. The emerging trends on access to higher education in India seems to inform that the social justice project is under severe threat. Private self-financing institutions, self-financing courses in public and private aided institution, hike in tuition fees limit the opportunities for the have-nots to access higher education. Some demand to widen caste-based reservation, some others demand to abolish the reservation based on caste backwardness and ask for reservation based on economic backwardness. Some demand fair and square reservation for all based on the population size of each caste and religion, while some others want to rely on pure academic merit and some favor a combination of several appraoches. A very few of the interviewees approved financial interest door, many interviewees appreciated classical merit door, while a majority of them acknowledge the importance of social responsive reservation door for access to higher education in India. Given the current context and developments in India, it is unclear how the tension over access, equity, social justice for access to higher education in India would be resolved. This study while problematizing the issue, attempt to provide multiple perspectives and views to the ongoing debate, which seemingly provide significant contribution to the political, policy making dialogues on access and equity in higher education in India.

\section{Higher Education Growth and Access in India}

According to British Council's (2012) higher education global trends and emerging opportunities 2020 document informs that the Indian higher education (HEd) is the third biggest in size next to China and the USA. It also predict that India will become to the $2^{\text {nd }}$ place by 2020 and will be the fast growing higher education sector in the world by 2020. The modern HEd system in India dates back to 1857, when the first three modern universities were set up at Bombay, Calcutta and Madras by the British. HEd plays an important role in national development. In the free India (since 1947), HEd was planned in view of national development. Jawaharlal Nehru, the first prime minister, believed that development must begin from the rural India, and therefore he established 
the first institute of national importance 'Indian Institute of Technology' at a rural village called 'Kharagpur'. Since independence Indian HEd has undergone a drastic change particularly in terms of expansion and inclusion. It is considered that equity cannot be achieved without enhancing capacity (David, 2011). Although there has been considerable growth in HEd in India, it is not remarkable when compared to other transition nations such as China. India should meet the aspiration of its youth of 18-25 years, who are over 150 million, yet only 25 million of them are enrolled in HEd. The National Knowledge Commission (NKC, 20o6), in its recommendations for HEd to the Prime Minister, proposed to raise the number of universities to 1500 by 2015. Altbach (2009) considers India and China as two giants that have awakened as they are sophisticating their economy, the market demands higher education expansion and high quality human capital in India and China. Although the growth of HEd in India is rapid and tremendous, it does not match the growing demands. Compared to other populous nations, the growth of HEd in India is not adequate. The aspiration for higher education of India's youth of 18-25 years, who are over 150 millions, is to be addressed. The National Knowledge Commission (NKC, 2006), in its recommendations for HEd to the Prime Minister, proposed to raise the number of universities to 1500 from its current number 345 by 2015 , which would enable $15 \%$ enrolments instead of its current $10 \%$. Indian HEd is the third biggest in size next to China and the USA. However, the growth India achieved is nothing compared to the achievement in China. Access to HEd in India was strongly driven by privatisation. The twelfth plan (2012) has six focus area on HEd, such as, expansion, equity, excellence, governance, funding, implementation and monitoring. 63.9\% of HEd institutions are unaided private and $58.9 \%$ of students are enrolled in unaided private HEd institutions.

The government at the federal level has taken several steps to reform HEd to be globally competitive and relevant. Shrivastava (2006) highlights some of the recent policy initiatives on HEd in India: such as the national policy on education (1986/1992/2000), establishment of National Assessment and Accreditation Council (NAAC), National Board of Accreditation (NBA), Technology Vision of India 2020 (1996), Information Technology Action Plan (1998), encouraging private investment in professional education, liberal grant of autonomy, deemed university status, setting up an educational satellite (2003), transforming India into a knowledge superpower vision (2003), draft national biotechnology plan (2004/05), upgrading technology education system - Tech Ed I, II, III and TEQIP, setting up of a knowledge commission (2005) and National Information Technology Act (2006).

Public policies evolved during and after the economic reform in the early 1990's advocated promotion of markets in HEd. Such policies demanded severe reforms in HEd. Government relaxed regulations for business to engage in profit making, which encouraged private investments in HEd. Thus more for-profit HEd institutions emerged, where students had to finance their education (David, 2011). Even public HEd institutions were advised to collect (at least $20 \%$ of the overall cost) student fees in the name of cost recovery and cost sharing. Growth in HEd was primarily driven by privatisation. Indian HEd growth is viewed as chaotic and unplanned. It is paradoxical to know that there is a shortage of skilled labour in India while a large number of graduates are unemployed (around 5 millions) due to a lack of industry required skills. Murthy (2005) calls for industry-university partnership in order to bridge this gap. India has the largest HEd system among the third world countries, and it is viewed as a model (as good or bad) for other third world countries.

Chitnis \& Altbach (1993) state that systemic reform in Indian HEd is difficult, given the complexity of the social context, in which Indian HEd exists, there seems to be only little scope 
for meaningful and systemic reforms. Agarwal (2006) points out that there has been unplanned growth, sub-standards, limited public resources, unorganised and unregulated private expansion, and political complexities involved in achieving systemic change. Anthuvan (2006) observes that neo-liberal agendas (such as privatisation and cutting public expenditure on social sectors) in social sectors such as education and healthcare were not strongly resisted by people in India. Agarwal (2006) points out that there is no strong HEd research institution available in India now. The absence of clear data in the HEd sector is another limitation for HEd research in India. The present Indian HEd system is very complex; it is by far the most fragmented system in the world. The average number of student enrolment in an institution in India is about 500-600, in the USA and Europe it is about 3000-4000, in China about 8000-9000. A greater number of HEdIs makes it difficult to manage them (Agarwal, 2006). Indian HEd also has to deal with different players involved in the system.

\section{Understanding Social Responsive Higher Education}

According to the economic and social research council (2008) there has been three policy moments in access to higher education globally, which took shift from elite to mass to universal participation. The first policy moment 'elite' advocated higher education 'for all those who are qualified by ability and attainment to pursue them and who wish to do so', the second policy moment 'mass' insisted access 'to all those who can benefit from higher education and who wish to do so', and the third policy moment 'universal participation' offers 'the opportunity of higher education to all those who have the potential to benefit' (The Economic and Social Research Council, 2008). These three policy moments have developed in a similar way in India as well with little difference. Higher education was luxurious and was only access to elites for long, the postcolonial, free India higher education was considered important for national building and it was expanded but with huge public investment, however the expansion since 1990's (since India's explicit engagement with neo-liberalism) purely was driven by privatisation of higher education as the public fund for higher education began to decline (Carnoy \& Dossani, 2013). This development has slowed down the democratic process for access to higher education in India and access to higher education was driven by more undemocratic means such a privatisation (David, 2014). Higher education institutions that have the status of institutions of national importance such as Indian Institute of Technology do not follow the national reservation policy (yet follow reservation in a different way) giving the rational of not diluting quality and strongly use merit door to admit students. All other public higher education institutions strictly follow the national reservation policy and strongly use social responsive - reservation door to admit students. The unaided self-financing higher education institutions do not follow national reservation policy and use economic responsive - financial interest door to admit students. The aided private not for profit higher education institutions follow national reservation policy and strongly use economic responsive - financial interest door to admit students. However, some public and aided private higher education institutions do not strictly follow national reservation policy, particularly in the self-financing courses, which are mostly offered in the evening shift.

According to the Bologna Declaration ${ }^{1}$ a social responsive university / higher education institution is 'broadly accessible', 'socially useful' and 'organizationally flexible' (Gaston, 2010). As this study focuses on access to higher education, the term 'broadly accessible' is more relevant for

\footnotetext{
${ }^{1}$ Bologna Declaration: is the main guiding document of the Bologna process. It was adopted by ministers of education of 29 European countries at their meeting in Bologna in 1999.
} 
this study. Bourdieu \& Passeron (1977) argued that education reproduces exiting social inequality and contended that social hierarchies are transformed into academic hierarchies. Archer (2003) indicate the reproduction of class differences referring to George Bernard Shaw who suggested that universities can be viewed as 'shops for selling class limitations'. Access in terms of equity is conveyed in a complex manner at the scholarly world, Andreasson, Ohlsson \& Assarson (2015) attempt to operationalize the values of equity that are negotiated, renegotiated and reshaped in daily contexts, which resulted in three overarching themes such as values as taken for granted, values as formalized and values as a pedagogical flow that are intertwined. The meritocracy rationale often is placed against the social justice demand in India, often claiming that universal access to education could be achieved only through equal opportunities. Amartya Sen (1999) in his capability approach points out that even with all resources and equality, there is no guarantee to achieve universal access to education. He therefore, proposes to balance fairness and inclusion (equal opportunity and equity) while addressing access to education.

David \& Wildemeersch (2014) identified the reproduction of caste hierarchy in the choice of course / subject selection among Indian students. Thus creating fair access to different class and caste groups are problematic and complex. Access to higher education in India could viewed with such complexity and tension. Privatisation trend particularly created an order in which the rich access well established private and public institutions, while the poor are left with substandard choices. This trend has creates economic homogenization and polarisation where diversity is withheld and several higher education institutions fail to ensure diversity. Gallagher (2005) suggests that if education is to serve as a vehicle for promoting a discourse of a common good and contribute to the construction of the architecture of a shared society then a more pro-active approach will be needed in future'.

To understand social responsive of higher education in India, one must understand the policy and political shift in India from socialism to neo-liberalism (Malay \& Arindam, 2003). Anthuvan (2006) distinguishes five major implications of neo-liberalism in Indian economy: 1. greater openness for international trade, 2. cutting public expenditure on social services, 3. reducing regulations for private markets, 4 . selling state owned enterprises and 5 . displacing the concept of 'public good' to individual responsibility. He remarks that neo-liberalism was accepted in India without rigorous resistance. The neo-liberal policy orientation in India has led for the growth of private higher education, which has halted and slowed the social justice project in India which radically helped for inclusion of traditionally excluded groups and a neo marginalization was re-stratified. Sharma (2005) accounts that though privatisation has created access to higher education, the household expenditure for education has increased in India during the last two decades. Knight (2009) remarks that financing access, equity and quality is challenging during the times of intensifying austerity in higher education, as no government around the globe is concerned about the long-term welfare of its citizens.

Apple (2001) considers that neo-liberalism transforms the state as an enterprise, yet he points out that although neo-liberalism and market may create space and access but has not proved the ability to foster social justice. This has been experienced in the case of India that India expanded higher education through privatisation but private institutions do not understand access in terms of equity and social justice. Tilak (2004) highlights the absence of policy perspectives to shape Indian higher education. Agarwal (2006) critiques that there are many contradictions in higher education policies, such as the rhetoric between access and social justice, creating world class standards vs declining of public funding and so on. The Yashpal committee 
report points out that higher education in India is chaotic and demands for a renovation and rejuvenation by various efforts (MHRD, 2009).

\section{Affirmative Actions and Access to Higher Education in India}

India is the one of the few countries that practice affirmative action in a large scale. The history of affirmative actions in India falls back to 1882, when Mahatma Jyotirao Phule made a demand for free and compulsory education for all along with proportionate reservation / representation in government jobs at Hunter Commission. Although several attempts have been made to include the historically excluded communities in education, the authentic moment was when it was constitutionalised in 1950 and was actively enforced since 1960. This was possible achieved with several efforts made by the leaders of scheduled castes and scheduled tribes, particularly by Dr.Ambedkar, who chaired the constitution drafting committee. Mahatma Gandhi believed it is against the fundamental principles of humanity, it is against the dictates of reason that a man should, by reason of birth, be denied or given extra privileges' (Jangir, 2013). Witenstein \& Palmer (2013) highlight that social and historical factors produce vast inequalities for access to educational opportunities. Blattel-Mink (2008) indicates social, cultural factors have strong quantitative and qualitative implications for gender inequality for higher educational opportunities.

The reservation system is considered as affirmative actions in India. The reservation policy in India is based on the constitution provision in article 15(1) and 29(2), to make special reservation for the advancement of any socially and educationally backward classes of citizens or for scheduled castes and scheduled tribes. The reservation system is caste based and does not consider economic disparity. Reservation was provided only for SC/ST till 1993 when it was extended to OBCs at the national level. This was a result of the Mandal Commission Report in 1991 (Das, 2000). The current reservation system (at national level) known as quota system in which $15 \%$ of seats are reserved for SC, $7.5 \%$ for ST and $27 \%$ for OBC. In case enough candidates do not meet minimum qualifying criteria as per written tests, SC/ST candidates are permitted a relaxation of $50 \%$ (Jangir, 2013). However the reservation for different caste groups differ from state to state depending upon the demographics of the caste groups. For example in Tamil Nadu the reservation for ST is only $1 \%$ while the reservation for ST in north eastern states are $80 \%$. Some states such as Andhra Pradesh and West Bengal has reservation for Muslims.

The twelfth plan (2012) highlights the disparity in gross enrolment ratio (GER) across the country. There is inter-state disparity; Delhi having the highest GER of $47.9 \%$, while Assam having the lowest of $9 \%$ (the national average is $18.5 \%$ ). GER of urban is $30 \%$, while rural is $11 \%$. GER of males is $19 \%$ and female is $15 \%$. And there has been a significant GER disparity found among difference caste groups; $14.8 \%$ other backward castes (OBC), $11.6 \%$ scheduled castes (SC), $7.7 \%$ scheduled tribe (ST), and 9.6\% Muslims. The GER of SC, ST, girls, women are lower than the national average. While India has one of the lowest access to higher education, there is a growing concern on graduate unemployment, yet huge number of Indian skilled labour force are leaving the country in search of jobs outside the country, such a trend of demand side vs supply side constraints has been marked as wastage in India higher education by Upadhyay (2007).

This reservation system is only practiced in public educational institutions and public sectors for jobs. Those supporting the reservation such as Das (2000) continue to demand to extend the system to private educational institutions and to private sectors for jobs. The right to education act 2009 (RTE, 2013) mandates private educational institutions to reserve $25 \%$ seats for 
economically weaker section (EWS) for whom the state pays the fees, however not many private institutions are not willing to admit students from EWS. Deshpande (2008) points out that the majority of targeted population have not benefited yet from affirmative action and therefore demands stronger implementation.

The critics of reservation system points out that while it might promote measure of equity, it is very costly exercise, resulting in loss of organizational efficiency, and arguably also a focus on excellence (Rizvi \& Gorur, 2011) and the critics demand for a fair reservation based on economic backwardness than caste backwardness (Sundaram, 2006). For Devy (2010) there has been a systemic discrimination against women and marginalized caste groups for over 2000 years in India, which therefore needs a systemic approach in effective inclusion. India has taken several measures to include the marginalized. There is a constitutional provision for the religious minorities to establish educational institutions. Several women's colleges and universities were established to include women. Relaxation on age and marks are given to underprivileged groups for education and jobs. The $12^{\text {th }}$ five year plan 2012-2017 (2011) envisages reducing educational disparities between regions, caste groups, religious groups and gender by instrumenting effective inclusive measures. Neelakandan \& Patil (2012) argue that the ideology of caste acquires new forms and strengthens the exclusion of marginalized caste groups particularly through rapid privatisation of higher education in India. David (2014) argues that the privatisation trend in India has further marginalised the marginalized for access to higher education as private institutions value financial merit over academic merit and does not include. Chattopadhyay (2009) argues that the market logic seriously comprises value and quality of higher education in India, which weakens the ability to build an inclusive society.

\section{Interview Results, Analysis and Discussion}

Semi structured qualitative interview was conducted among 100 selected participants from four selected higher education institutions in Chennai, India. Among the four institutions: one is central government funded public higher education institution, one is state government funded public university, one is state aided not-for-profit private autonomous college and another is a non-public funded for-profit self-financing private university. The state government public university do offer self-financing courses where the fee is higher than in the subsidized courses. The state aided not-for-profit private college has two shifts; the morning shift offer subsidized courses and the evening shift offers self-financing courses. As several of the participants did not like to disclose their identity and the identity of their institution, the names of the institutions and the participants are kept confidential.

The central government funded institution is one of the institutions of national importance and follows the national reservation policy ( $15 \%$ for SC, $7.5 \%$ for ST, 27 for OC, total reservation $49.5 \%$ ) with a possibility for the unfilled reserved seats to be transferred to general category. The state funded public university follows the Tamil Nadu state government reservation policy (BC 30\%, MBC 20\%, SC 18\%, ST 1\%, total of 69\%). The Tamil Nadu state aided autonomous not for profit private college has two shifts (morning shift is state aided, evening shift selffinancing). The college follow Tamil Nadu state government reservation policy ( $\mathrm{BC} 30 \%$, MBC $20 \%$, SC $18 \%$, ST $1 \%$, total of $69 \%$ ) with some exception to admit more Dalit ${ }^{2}$ (SC) and Christian students, given their status as a Christian minority institution, however there are no clear

\footnotetext{
${ }^{2}$ Dalit means, a member of the lowest caste, in the traditional Indian caste system. Other meanings include; anyone who is oppressed, formerly called (offensive) untouchable.
} 
information about the reservation policy on the self-financing stream. There is no clear information about the reservation policy from the for profit self-financing private university studied, although this is has obtained Christian minority institution status.

Table 1: Demographics of the respondents in the interview

\begin{tabular}{|c|c|c|c|c|}
\hline & $\begin{array}{c}\text { Central public } \\
\text { institution }\end{array}$ & $\begin{array}{c}\text { State public } \\
\text { institution }\end{array}$ & $\begin{array}{c}\text { Private aided } \\
\text { institution }\end{array}$ & $\begin{array}{c}\text { Private unaided } \\
\text { institution }\end{array}$ \\
\hline \multicolumn{5}{|l|}{ Profile } \\
\hline Students & 5 & 5 & 5 & 5 \\
\hline Parents & 5 & 5 & 5 & 5 \\
\hline Academic & 5 & 5 & 5 & 5 \\
\hline Administrators & 5 & 5 & 5 & 5 \\
\hline Others & 5 & 5 & 5 & 5 \\
\hline \multicolumn{5}{|l|}{ Gender } \\
\hline Male & 12 & 12 & 13 & 12 \\
\hline Female & 13 & 13 & 12 & 13 \\
\hline \multicolumn{5}{|l|}{ Caste } \\
\hline FC & 6 & 4 & 3 & 5 \\
\hline $\mathrm{BC}$ & 4 & 5 & 4 & 4 \\
\hline OBC & 5 & 6 & 5 & 6 \\
\hline $\mathrm{SC}$ & 7 & 6 & 7 & 7 \\
\hline ST & 3 & 4 & 6 & 3 \\
\hline \multicolumn{5}{|l|}{ Interview type } \\
\hline Face to face & 20 & 18 & 22 & 17 \\
\hline Telephone & 5 & 7 & 3 & 8 \\
\hline
\end{tabular}

The 100 interviewees were asked to share their views on the following questions: 1. Views on access to higher education in India, 2. Trends and status of student admission in your institution, 3. Views on the three dominant admission strategies - merit door, reservation door and financial interest door, 4. Views on equity vs equal opportunity? 5. Any other views? most of the interviews were conducted face to face, while some of them (mostly parents) were conducted over telephone. The interviews are selected purposefully. Equal size of samples were selected from the four institutions (25 interviewees per institution). Equal representation was considered and maintained in the choices of the interviews who are students, parents, academic, administrators and others (who are general public related to the respective institutions) in order to get views from different stakeholders. And sufficient attention was given in the selection of the interviews in terms of their caste background such as FC, BC, SC and ST in order to get diverse viewpoints with some attention to socio-economic and socio-religious background.

Table 2: General views emerged in the interview

\begin{tabular}{|c|c|c|c|c|}
\hline & $\begin{array}{l}\text { Central public } \\
\text { institution }\end{array}$ & $\begin{array}{l}\text { State public } \\
\text { institution }\end{array}$ & $\begin{array}{l}\text { Private aided } \\
\text { institution }\end{array}$ & $\begin{array}{l}\text { Private unaided } \\
\text { institution }\end{array}$ \\
\hline $\begin{array}{l}\text { Views on access } \\
\text { to higher } \\
\text { education }\end{array}$ & $\begin{array}{l}\text { Access to all who } \\
\text { are able to study. }\end{array}$ & $\begin{array}{l}\text { Access to all who } \\
\text { has desire to } \\
\text { study. }\end{array}$ & $\begin{array}{l}\text { Access to all who } \\
\text { is able and } \\
\text { desired. }\end{array}$ & $\begin{array}{l}\text { Access to all who } \\
\text { has desire and } \\
\text { able. }\end{array}$ \\
\hline $\begin{array}{l}\text { Trends } \\
\text { student } \\
\text { admission in } \\
\text { your institution } \\
\end{array}$ & $\begin{array}{l}\text { Admission trend } \\
\text { based on merit } \\
\text { and reservation. }\end{array}$ & $\begin{array}{lr}\text { Admission } & \text { trend } \\
\text { based } & \text { on } \\
\text { reservation, } & \\
\text { merit. } & \\
\end{array}$ & $\begin{array}{l}\text { Admission trend } \\
\text { based on merit } \\
\text { and reservation. }\end{array}$ & $\begin{array}{l}\text { Admission trend } \\
\text { based on financial } \\
\text { ability and merit. }\end{array}$ \\
\hline Views on merit & favored & Most favored & favored & Most favor access \\
\hline
\end{tabular}




\begin{tabular}{|l|l|lr|l|l|}
\hline $\begin{array}{l}\text { door, on based on } \\
\text { reservation door } \\
\text { and financial } \\
\text { interest door }\end{array}$ & $\begin{array}{l}\text { access based on } \\
\text { merit. }\end{array}$ & $\begin{array}{l}\text { access based on } \\
\text { financial interest } \\
\text { and reservation. }\end{array}$ & $\begin{array}{l}\text { based on financial } \\
\text { interest and } \\
\text { merit. }\end{array}$ \\
\hline $\begin{array}{l}\text { Views on equity } \\
\text { vs equal } \\
\text { opportunity }\end{array}$ & $\begin{array}{l}\text { Equal opportunity } \\
\text { is preferred. }\end{array}$ & $\begin{array}{l}\text { Equity is } \\
\text { preferred. is }\end{array}$ & $\begin{array}{l}\text { Equity } \\
\text { preferred. }\end{array}$ & $\begin{array}{l}\text { Equal opportunity } \\
\text { is preferred. }\end{array}$ \\
\hline
\end{tabular}

The interview analysis provide different views and perspectives about the trends on access and the way the problem has to be approached. The above table indicates the general views that emerged from the interview. The dominant views from the four institutions for the four key questions indicate the type of stakeholders with specific views. Most of the interviewees from the central institution favored merit door, preferring equal opportunity, while most of the interviewees from the state institution favored reservation and merit, preferring equity. Most of the interviewees at the private aided institution favored merit and reservation, preferring equity, while most of the interviewees at the private unaided institution favored financial interest and merit, preferring equal opportunity. Most of the interviewees were happy about the growth of higher education and the expansion of access to higher education in India. Several of them highlighted the raise of the cost of higher education, which restricts opportunities for economically vulnerable community. Considerable number of interviewees insisted on access based on academic merit irrespective of caste and creed, while indicting that the current reservation policy reduces the opportunity for students with good academic background. Several of them pointed out the need for economic based reservation rather caste based reservation indicating the opportunity for the creamy layers from the backward castes enjoying the reservation policy for long time and the system does not truly benefit the people in real need. Sizable number of interviewees expressed that the current reservation policy helped several individuals to raise their social and economic status and they insisted that the reservation policy must continue and help the backward community.

Some of the interviewees demanded to make a fair and square reservation policy (representative), to allot seats based on the population of each caste and religious groups. For them this will ensure equal opportunity for everyone. Only a few favored the financial merit option as a route for access to higher education, indicating the possibility for those to seize the opportunity who are willing to invest in their education and yet not able to achieve it through merit or reservation route. Some of the interviewees found a value in all the three approaches for access to higher education. Some of the interviewees pointed out that it has become a trend for many communities to demand for special category status that would bring them reservation benefit, for which they are willing to go (socially) backward to (economically) forward themselves.

It was interesting to observe that most of the female respondents were highlighting the gender disparity in access to certain programmes in all the four institutions, highlighting the conservative approach for female access to higher education. Unlike other states in India, the access to education for the religious minorities in Tamil Nadu is relatively well address, given the long presence of the religious minority institutions. Religion was a not a big factor of the responses in the two public institutions while in the two private institutions studied, several stakeholders were highlighting the opportunities and challenges for different religious groups. Caste was the big focus of the discussion with all the stakeholders from all the institutions, with some attention to the different income level groups. Several respondents from the central public and self-financing institutions demanded income level as indicator for affirmative action. 
Students, parents and academic were passionate about participating in the study, while not much enthusiasm were found among administrators and general public (with some exceptions).

Some of the interviewees from the central government funded institution insisted that institutions of national importance must focus admission based on academic merit as it is important for institutes of national importance to deliver quality, while some others from the same institute demanded to create space for all and they highlighted that the current student and faculty representation in this institution is not reflecting the reservation policy. Some of the interviewees from the state funded public university were proud of the university's social responsive role by implementing the state government's reservation policy, while some others indicated that reservation policy is not strictly practiced at self-financing courses at the university, a few of them pointed out that most of the students who benefit from reservation policy are from urban and creamy layer category. Several interviewees from the state aided not-for-profit private college were happy about the decision of the college to support economically and socially vulnerable community by admitting them in the subsidized morning shift where the tuition fee is less and by admitting economically, socially advanced community in the self-financing evening shift where the tuition fee is relatively higher than the morning shift. Some of the interviewees accused the college for being favorable for only Christian and dalit students, while others indicated that the college is a Christian minority institution and it finds a value in supporting the oppressed. Most of the interviewees from the for-profit self-financing private university pointed out that the university only uses financial interest option to admit students for the reason the university has to generate revenue only through this mean as the university does not receive any public fund. Most of the interviewees indicated that there is no big attention for reservation policy, while the administrators informed that the university provide scholarship for some poor students. Some of the interviewees accused the university for misusing Christian minority status and ignore state admission policy (minority institutions are exempted from reservation policy and share less percent of seats for government quota unlike other self-financing private institutions) to economically benefit.

In general, the views of the stakeholders from the four institutions reflected to large extend the nature and the type of the institution that they were affiliated to, as their personal values correlated with the values of their respective institutions. However, there were exceptions with some counter views often critical about the approaches used by their respective institution, which indicated the nature and complexity of the problem. The findings confirm the initial assumption of the study that privatisation of higher education and the emergence of selffinancing programmes and institutions have slowed down and posed new challenges to the social justice agenda.

\section{Conclusion}

The literature review suggests that higher education has expanded in India recently given the demographic rise, economic transformation and social justice demands. Public spending for higher education has not grown in proportion to the demand for access and expansion, which has caused the emergence of self-financing programmes in public and aided institutions and the establishment of self-financing private institutions. This trend particularly has slowed the popular democratic development for inclusion of the traditionally excluded groups in higher education and a neo marginalization has been caused in India by privatization trends where financial merit is valued more than academic merit, which does not support the social justice project. The three dominant approaches for access to higher education, such as the merit door, reservation door and 
financial interest door prevails in access to higher education in India. Higher education institutions in India use one specific or the combination two or three approaches based on their nature, values and priorities.

The four higher education institutions studied in this research confirm the above presented argument. A very few of the interviewees approved financial interest door, many interviewees appreciated classical merit door, while a many others acknowledge the importance of social responsive reservation door for access to higher education in India. The diverse perspectives emerged out of interview indicate the complexity to deal with fair educational opportunities for all in India. Private self-financing institutions, self-financing courses in public and private aided institution, hike tuition fees to limit the opportunities for the have-nots to access higher education. Some demand to widen caste-based reservation, some others demand to abolish the reservation based on caste backwardness and ask for reservation based on economic backwardness. Some demand fair and square reservation for all, based on the population size of each caste and religion, while some others want to rely on pure academic merit and on the intellectual capability.

The purpose of the study has been achieved as the study accounted and discussed multiple perspectives on access, equity and social justice in higher education in India. Both the theoretical and empirical exploration confirmed that the access to higher education in India is achieved through all the doors, such as; the merit, reservation, financial interest as assumed. The study to large extend attempted to answer the four research questions. The study answered the first two questions by presenting the general trends for access to higher education in India and on how the social justice agenda is approached for access to higher education in India through literature review and document analysis. The third research question was answered from the analysis of the interview responses by accounting different perspectives from the respondents and the analysis and discussion answered the fourth question about how these perspectives shape the trend and the ongoing debate on access, equity and social justice in higher education in India. The social justice agenda for access to higher education in India for some has made remarkable contribution, for some others it has not made big difference, while for some it reduces the opportunity of others, and for some other the social justice agenda has to evolve to help all in need beyond the caste based reservation. The views of the interviewees differed based on the ideological position and institutional belonging, which does not lead to build consensus.

The emerging trends in India suggests that the social justice project is under severe threat. Given the current context and developments on access to higher education in India, it is unclear how the tension between neo-liberal and social justice discourse would be resolved. One of the critical demands for higher education institutions in India is to effectively deal with complex Indian social context, which will help India to embrace access, equity and social justice rather embarrassing. In addition, it is important to constantly dialogue and shape the social justice agenda based on the emerging demands. The theoretical and empirical finding of this study indicate that the more progressive the higher education in terms of its social responsiveness, particularly for access to higher education, the more possibility would emerge for proactive educational change. The study argues that it is important that higher educational institutions to uphold social responsiveness by embracing equity and social justice. Moreover, it is important to raise conscious about the social responsiveness of higher education among various stakeholders and accounting divergent perspectives contribute to engineer fair and just society. 


\section{References}

Agarwal, P. (2006). Higher Education Policy: Many Contradictions. Economic and Political Weekly. 41(45), $4645-4648$.

Agarwal, P. (2007). Higher Education in India: Growth, Concerns and Change Agenda. Higher Education Quarterly, 61(2), 197-207.

Altbach, P., G. (2009). The Giants Awake: Higher Education Systems in China and India. Economic and Political Weekly. 44(23), 39-51.

Anderasson, I., Ohlsson, L., \& Assarson, I. (2015). Operatizing equity: The complexities of equity in practice. Education, Citizenship and Social Justice. 10(3), 266-277.

Anthuvan, M. V. L. (2006). The Dynamics and the impact of Globalisation: A Subaltern Perspective. Madurai: Amirtham Publications.

Apple, M. W. (2001). Comparing Neo-liberal Projects and Inequality in Education. Comparative Education, $37(4), 409-423$.

Archer, L., Hutchings, M., \& Ross, A. (2003) (Eds.). Higher Education and Social Class - issues of exclusion and inclusion. London: Routledge Flmer.

Blattel-Mink, B. (2008). Reinventing gender in higher education. Equal Opportunities International. 27(1), 107-111.

Bourdieu, P. \& Passeron, J.C. (1977). Reproduction in Education, Society and Culture. London: Sage.

British Council (2012). The shape of things to come: higher education global trends and emerging opportunities to 2020. British Council.

Carnoy, M., \& Dossani, R. (2013). Goal and Governance of Higher Education in India. Higher Education (2013). 65, 595-612.

Chattopadhyay, S. (2009). The Market in Higher Education: Concern for Equity and Quality. Economic and Political Weekly, 44(29), 53-61.

Chitnis, S., \& Altbach, P. G. (1993). Higher Education Reform in India: Experience and Perspectives. New Delhi: Sage Publication.

Das, B. (2000). Moments in a History of Reservations. Economic and Political Weekly. October 200o. WS-31. $3831-3834$.

David, S. A. (2011). Economic Globalisation and Higher Education Curriculum Restructuring: Exploring the Trends in the States of Kerala and Tamil Nadu of India. LAP Lambert Academic Publishing, Saarnricken, Germany.

David, S. A. (2014). Economic Globalisation and Higher Education Transformation: Comparing the Trends in the States, Kerala and Tamil Nadu of India. Journal of Social Sciences. 38(3), 283-292.

David, S. A. \& Wildemeersch D (2014). Impact of Globalisation on Higher Education Curriculum Restructuring in India: Comparing the Trends in Kerala and Tamil Nadu. The Indian Journal of Social Work, 75(4), 489-63.

Deshpande, A. (2008). Quest for Equality: Affirmative Action in India. Indian Journal of Industrial Relations. 44(2), 154-163.

Devi, G. N. (2010). Inclusive Education A View of Higher Education in India. Public Lecture Series, 26-o92010. National Institute of Advanced Studies, Bangalore, India.

Fraser, N. 2008. Adding insult to injury: Nancy Fraser debates her critics, ed. K. Olson. USA: Verso Publishers.

Gallagher, T. (2005). Balancing difference and the common good: lessons from a post-conflict society. Compare: A Journal of Comparative and International Education.35(4), 429-442.

Gaston, L. P. (2010). The Challenges of Bologna What United States Higher Education Has to Learn From Europe, and Why It Matters that We Learn it. Sterling, Virginia: Stylus Publishing, LLC, 18.

Indian Institute of Technology Bombay (2014). https://www.iitb.ac.in/about/about_iitbNew.html

Jangir S. K. (2013). Reservation Policy and Indian Constitution in India. American International Journal of Research in Humanities, Arts and Social Science. 126-128.

Knight, J. (2009). Financing Access and Equity in Higher Education. Global Perspectives on Higher Education. Rotterdam: Sense Publishers. 
Ministry of Human Resource Development of India (2009). Yashpal Committee Report on Renovation and Rejuvenation of Higher Education. MHRD: New Delhi.

Ministry of Human Resource Development of India. (2013). www.education.nic.in

Ministry of Human Resource Development of India. (2015). All India Survey on Higher Education. MHRD: New Delhi.

Malay, C., \& Arindam, C. (2003). The Great Indian Dream: Restoring pride to a nation betrayed. New Delhi: Macmillan India Ltd.,

Murthy, N. R. N. (2005). Government regulation stifling higher education. United News of India, Kochi.

Neelakandan, S. M. \& Patil, S.M. (2012). Complexities of inclusion and exclusion: Dalit students and higher education in India. Journal of Social Inclusion 3(1), 86-100.

NKC. (2006). National Knowledge Commission Report: Recommendations for Higher Education. New Delhi: National Knowledge Commisison.

Planning Commission (2011). Faster, Sustainable and More Inclusive Growth An Approach to the Twelfth Five Year Plan. Planning Commission, New Delhi, India.

Planning Commission (2012). Higher Education in India: Twelfth Five Year Plan (2012-2017) and beyond. FICCI Higher Education Summit 2012. Planning Commission, New Delhi, India.

Pondicherry University (2014). http://www.pondiuni.edu.in/

Rizvi, F. \& Gorur, R. (2011). Challenges Facing Indian Higher Education. Fearless Nadia. Occasional Paper on India Australia Relations. Winter 2011. 1-14.

RTE (2013). Right to Education, India. http://righttoeducation.in/

Sen, A. (1999). Development as Freedom, Alfred A. Knopf: New York

Sharma, V. (2005). Commercialisation of Higher Education in India. Social Scientist, Vol.33, No.9/10, 65-74.

Shrivastava, S. K. (2006). Higher Education System in India: Challenges $\mathcal{E}$ Strategies for Reform. Presented at the Washington Symposium NAFSA: Association of International Educators, 28/03/2006.

Sundaram, K. (2006). On Backwardness and Fair Access to Higher Education: Result from the NSS $55^{\text {th }}$ Round Surveys. 1999-200o. Economic and Political Weekly. 41(50), 5173-5182.

Tilak, J.B.G. (2004). Absence of Policy and Perspective in Higher Education. Economic and Political Weekly. 39(21), 2159-2164.

The Economic and Social Research Council, (2008). Widening Participation in Higher Education. TLRP: London.

University of Delhi (2014). http://www.du.ac.in/fileadmin/DU/about_du/newdu/index.html

Upadhyay, S. (2007). Wastage in Indian Higher Education. Economic and Political Weekly. 42(2),161-168.

Witenstein, M. A. \& Palmer, B. (2013). Inequality of participation in Nepalese higher education A critical conceptual model of educational barriers. Asian Education and Development Studies. 2(2), 162-176. 